\title{
Impact of the use of sexual material and online sexual activity during preventive social isolation due to COVID-19
}

\author{
José Luis Hernández-Torres, ${ }^{1}$ Nancy Rodríguez-Vázquez, ${ }^{2}$ Roxana Martínez-Cervantes, ${ }^{1}$ Adriana Mayela \\ Cárdenas-Cortés, ${ }^{1}$ Dafne Astrid Gómez-Melasio, ${ }^{3}$ Pedro Enrique Trujillo-Hernández ${ }^{3}$
}

' Escuela de Licenciatura en Enfermería, Unidad Torreón, Universidad Autónoma de Coahuila, México.

2 Facultad de Enfermería, Universidad Autónoma de Nuevo León, Ciudad de México, México.

${ }^{3}$ Facultad de Enfermería, Unidad Saltillo, Universidad Autónoma de Coahuila, Torreón Coahuila, México.

Correspondence:

José Luis Hernández Torres

Escuela de Licenciatura en Enfermería,

Unidad Torreón, Universidad Autónoma de Coahuila.

Monte Vesubio S/N, Fracc. Valle

Dorado, 27298, Torreón, Coahuila,

México.

Phone: +52 (871) 721-9054

Email: torres luis@uadec.edu.mx

Received: 7 November 2020

Accepted: 22 January 2021

Citation:

Hernández-Torres, J. L., Rodríguez-Vázquez, N., Martínez-Cervantes, R., Cárdenas-Cortés, A. M. Gómez-Melasio, D. A., \& Trujillo-Hernández, P. E. (2021). Impact of the use of sexual material and online sexual activity during preventive social isolation due to COVID-19. Salud Mental, 44(4), 185-192.

DOI: $10.17711 /$ SM.0185-3325.2021.024

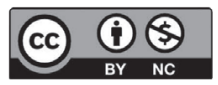

\begin{abstract}
Introduction. Preventive social isolation due to coronavirus disease (COVID-19) has represented one of the greatest health challenges of the last decades worldwide. As a result of social isolation, the consumption of information in digital media, such as the use of online sexual material, has increased, leading to risky sexual behavior in young people. Objective. To quantify the impact on the use and type of online sexual material and to determine the predictors of online sexual activity in people in preventive social isolation due to COVID-19. Method. Multivariate cross-sectional study; 385 participants were studied and contacted through an online survey. Results. Internet pages and social networks are the main platforms for the use of online sexual material, and its consumption was more frequent in those who had more days of preventive social isolation. Predictors of sexual activity were cybersex $(\beta=.38)$, excitation $(\beta=.36)$, masturbation $(\beta=.34)$, and adventure $(\beta=.33)$, which were found to be statistically significant $(p<.001)$. Discussion and conclusion. Privacy plays an important role in the use of online sexual material and activities, and greater consumption can be found in intimacy. It is important to be alert to the effects of the pandemic on sexual risk behavior and further research is needed.
\end{abstract}

Keywords: Online sexual material, preventive social isolation, sexual behaviour, sexuality, COVID-19.

\section{RESUMEN}

Introducción. El aislamiento social preventivo por la enfermedad por coronavirus (COVID-19) ha representado uno de los mayores retos de salud en las últimas décadas en todo el mundo. Como resultado del aislamiento social se ha elevado el consumo de información en medios digitales, como el uso de material sexual en línea, lo que ha propiciado un comportamiento sexual de riesgo en los jóvenes. Objetivo. Cuantificar el impacto en el uso y el tipo de material sexual en línea y determinar los predictores de actividades sexuales en línea en personas en aislamiento social preventivo debido al COVID-19. Método. Estudio multivariado de corte transversal; se estudiaron 385 participantes contactados por medio de una encuesta en línea. Resultados. Las páginas de internet y las redes sociales son las principales plataformas para el uso de material sexual en línea y este consumo se dio con más frecuencia en quienes tenían más días de aislamiento social preventivo. Los predictores de las actividades sexuales fueron el cibersexo $(\beta=.38)$, la excitación $(\beta=.36)$, la masturbación $(\beta=.34)$ y aventura $(\beta=.33)$, encontrándose estadísticamente significativas $(p<.001)$. Discusión y conclusión. La privacidad cumple un papel importante en el uso de material y actividades sexuales en línea, en la intimidad se puede encontrar un mayor consumo. Es importante estar alerta a los efectos que la pandemia causa en relación a las conductas sexuales de riesgo y seguir investigando sus efectos es necesario.

Palabras clave: Material sexual en línea, aislamiento social preventivo, comportamiento sexual, sexualidad, COVID-19. 


\section{INTRODUCTION}

The world has changed because of the coronavirus disease or COVID-19. This pandemic changed the dynamics in the lives of millions of people as a result of preventive social isolation enforced as a universal action to prevent the rapid spread of the virus (World Health Organization [WHO], 2019) so today the use of the internet has become an ally to reduce geographical and economic gaps. With preventive social isolation, the use of social networks such as YouTube, Facebook, WhatsApp, audiovisual content platforms, as well as access to online pages, have been the main showcases for people's entertainment during the COVID-19 confinement, especially in the 15-49 age group (Subía-Arellano, Muñoz, \& Navarrete, 2020).

Today, due to this overexposure to digital media, people may be in greater contact with the use of online sexual material, which is defined as an interaction with various digital materials such as internet pages, email, chat, online video channels, video calls, social networks, online forums for the purpose of sexual activity, mainly masturbation, stimulation, excitation, seeking sexual adventures, gathering people for sexual encounters, sharing images with sexual content and the practice of cybersex (Valdez Montero, 2011).

It is surprising how anyone who is in front of a device with an internet connection can reach with just a few clicks explicit sex content such as pornography, but what is really worrying is that some viewers, mostly young people, manipulate what they see on a screen to practice assuming it as reality (Hernández Torres, Benavides Torres, González y González, \& Onofre Rodríguez, 2019).

In this atypical situation, the use of online sexual material may be subject to uncontrolled measures. On the one hand, people facing the risk of contagion by COVID-19 take shelter at home to prevent the disease; on the other, they are exposed to online content that may produce a risk to their sexual health (Folch, Álvarez, Casabona, Brotons, \& Castellsagué, 2015; Shallo \& Mengesha, 2019; Valdez Montero, Benavides Torres, González y González, Onofre Rodríguez, \& Castillo Arcos, 2015).

New studies have found that during the COVID-19 pandemic, the use of sexual material and online sexual activities are increasing due to confinement, Pornhub, the world's leading pornography website, reports a meteoric rise during the pandemic, the site receives 37 million visits per year with $47 \%$ more online traffic than normal. Likewise, sexual activities such as masturbation, excitation, and sharing images with sexual content were frequent activities of internet users during preventive social isolation due to COVID-19 (Ibarra et al., 2020). It was also found that there are variables that are positively related to these behaviors such as masturbation, excitation and cybersex (Subía-Arellano et al., 2020; Uzieblo \& Prescott, 2020).
The consumption of online sexual material and the practice of online sexual activities may encourage risky sexual behaviors in users because the materials they watch and the high predisposition of their use due to the COVID-19 pandemic suggest a risk to people's sexual health (Valdez Montero et al., 2015). It is important to quantify its use in order to identify risk behaviors in the population in a timely manner and in this way take care of people's sexual health. In this sense, the World Health Organization refers to sexual health as a state of physical, mental, and social well-being in relation to sexuality; it is not merely the absence of disease, dysfunction or infirmity. Sexual health requires a positive and respectful approach to sexuality and sexual relationships, as well as the possibility of having pleasurable and safe sexual experiences, free of coercion, discrimination, and violence (Fernández Velasco, 2018).

Part of the theoretical explanation concerning the risk of using online sexual material, Fishbein and Ajzen in their theory of reasoned action postulate that, if a person perceives that there is a benefit in engaging in a certain observed behavior, he or she is more likely to carry it out (Fishbein \& Ajzen, 2011; Yzer, 2012). At this point Albert Bandura in his social cognitive model mentions that sexual behavior is acquired and learned through observation and that this has a significant impact on learning and modeling behavior (Bandura, 2011; Glanz, Rimer, \& Viswanath, 2008).

In turn, Prochaska and Di Clemente refer in their trans-theoretical model that when people have an addictive or problematic behavior, sometimes the first stage of those people can be the denial or even be in the unconsciousness of having it, because the human being to make a change of habit first requires being aware of having a problem, therefore, the person may be in a pre-contemplation phase (Glanz et al., 2008; Prochaska et al., 1994).

In this vein, recent research on the use of online sexual material suggests that explicit sex viewing may be negatively related to risky sexual behavior, such as sexually transmitted infections (STIs), incorrect and inconsistent condom use, multiple sexual partners, sexual activity with drug use, and early sexual debut (Eversole, Berglas, Deardorff, \& Constantine, 2017; Hald, Kuyper, Adam, \& de Wit, 2013; Hernández Torres, Benavides Torres, Onofre Rodríguez, \& Jiménez Vázquez, 2018; Koletić, Štulhofer, Tomić, \& Knežević Ćuća, 2019; Shallo \& Mengesha, 2019).

Social networks such as YouTube, Facebook, WhatsApp, and others spread and promote the use of online sexual material in video, audio, or text format. Among the most common forms, video calls, e-mails, online forums are means by which people commonly come in contact with online sexual material. Pornography, nudity, sexual conversations, cybersex, etc. are all stimuli for people to engage in risky sexual behaviour in order to acquire an STIs or even HIV. Similarly, adventure is an activity that takes place on- 
line for the purpose of having sex usually with casual partners (Castillo-Arcos, Benavides-Torres, \& López-Rosales 2012; García-Vega, Menéndez, Fernández, \& Cuesta, 2012; Hernández Torres et al., 2018; Valdez Montero et al., 2015).

According to the Organización de Estados Iberoamericanos (OEI, Organization of Ibero-American States), by its Spanish acronym, recently conducted a census in Mexico in which it quantified that nine out of ten Mexicans said they had consulted pornography of various types on the internet in search of movies or images. Similary, more than $40 \%$ of the participants reported maintaining erotic contact by chat and $35 \%$ by webcam with strangers (Organización de Estados Iberoamericanos [OEI], 2016). In addition, the Asociación Mexicana de Internet (AMIPCI, Mexican Association of Internet) by its Spanish acronym, refers that the number of internet users is increasing, and it has been quantified that there are more than 58 million cybernauts and that on average each person spends more than eight hours a day to be surfing the internet, most of them do it from their smart phone because in this way they have greater ease of access and privacy when surfing the internet (AMIPCI, 2016).

Therefore, the purpose of the present study was to quantify the impact on the use and type of online sexual material and to determine the predictors of online sexual activity in people in preventive social isolation due to COVID-19.

\section{METHOD}

\section{Design of the study}

A multivariate cross-sectional study was carried out between March and June 2020 in the city of Torreón Coahuila, Mexico. There were 385 participants in the sample and they were calculated with the statistical program nQuery Advisor 7.0 for Windows, with a 95\% confidence level and an acceptable error of $5 \%$ for a design effect of 1.0 and power of $90 \%$ (Cohen, 2013; Grove, Burns, \& Gray, 2013). Participants had to meet the following inclusion criteria: be over 18 years old, navigate the internet with a mobile or fixed device, and be in preventive social isolation in their homes due to COVID-19 at the time of data collection. No participants were eliminated from the study. In the present study the following research hypothesis was posed: youth used social networks as the main type of online sexual material, masturbation and excitation, which were the main predictors of online sexual activities during preventive social isolation due to COVID-19.

\section{Measurements}

A data sheet was used to meet the inclusion criteria, and some questions were added to the data sheet to find out about the general demographics of the participants. The use of online sexual material and sexual activity were measured with an automated web-linked instrument composed of 43 items, which measured the type of sexual material, coercive use, problematic use, and online sexual activities. For the purposes of this study, only two dimensions of the instrument were used: the type of sexual material online with eight items; an example of a question is: Do you think that watching sexual material online is not as bad as doing it live? The response options for this dimension ranged from completely disagree $=1$ to completely agree $=5$. It is worth mentioning in this dimension that participants were able to select more than one type of online sexual material, which means that each participant was able to choose more than one response option which will be reflected in the frequencies and percentages of the type of online sexual material, and the online sexual activities dimension counts 16 items, an example question is: Have you masturbated using internet pages with sexual material? The response options for this dimension ranged from never $=0$ to always $=4$, with both dimensions having an ordinal measurement level. This instrument has been previously validated in Mexican population with Cronbach's alpha 72 (Benavides, Valdez Moreno, González, \& Onofre Rodríguez, 2012; Valdez Montero, 2011).

\section{Procedure}

The SurveyMonkey tool was used to apply the instrument through a web link starting in March 2020. As a strategy for data collection and in accordance with the recommendations of the COVID-19, the general population was invited to participate in the study through the website of the Universidad Autonoma de Coahuila's newsletter and social networks were also used to extend the invitation to potential participants, in those platforms appeared the web link that redirected them to the survey in the SurveyMonkey platform. The present study complied with the General Health Law of the Secretaría de Salud (SSA, Secretary of Health), in the area of Health Research, in attention to Chapter I, referring to the ethical aspects of research on human beings, articles 13 and 14 specifically to the anonymity of the participants and the informed consent of participation (Secretaría de Salud [SSA], 1987).

\section{Statistical analysis}

Once the data was collected through the SurveyMonkey platform, it was exported to the Statistical Package for the Social Sciences (SPSS) version 23 program. Kolmogorov Smirnov's test was performed to determine if the distribution of the data followed a normal pattern. At this point, the reliability calculation of Cronbach's Alpha was also performed to calculate the adjustment of the applied instrument. For the data management, central tendency measures, percentages and frequencies were used to quantify the impact on the use and type of sexual material online. It should be noted 
that in the dimension that measures this variable, the participant could choose more than one answer option and that was particularly consistent with the objective of quantifying the use and type of online sexual material. For this reason, a regrouping of this variable with multiple responses was not used, that is, the final quantification of frequencies and percentages will then be higher than the sample. To determine the predictors of online sexual activities, multiple linear regression models were carried out with the method of successive steps and as a credibility criterion the assumptions of independence of the residues with the Durbin Watson statistic with values close to 2 and the assumption of normality of the residues for each of the online sexual activities were considered. In addition, for external validity the cross validation of the model was used by calculating the mean square error and the criterion of the sample size per input variable (Cohen, 2013; Miles, Huberman, \& Saldana, 2013).

\section{Ethical considerations}

This research was carried out in accordance with ethical standards from the Universidad Autónoma de Coahuila of the Escuela de Licenciatura en Enfermería - Unidad Torreón, of the institutional review protocol (20CEI024201141127), in Mexico City.

\section{RESULTS}

The average age of the participants was 27 years $(S D=8.31$; $\min =18, \max =58) 68.3 \%$ were female and $31.7 \%$ were male, $41.6 \%$ were single, while $23.1 \%$ were married. Regarding the days of preventive social isolation by COVID-19, participants reported an average of 15.5 days $(S D=1.80$; $\min =1, \max =40$ ), the lowest percentage was obtained by those who had less than ten days in preventive social isolation with $7.5 \%$ and most of them had more than 20 days of quarantine with $22.6 \%$. Forty-one percent of the participants were single, and $23.1 \%$ were married and in a dating relationship (Table 1).

It is worth mentioning that $41 \%$ were alone at the time of accessing online sexual material during preventive social isolation. Kolmogorov Smirnov's normality test was carried out in the construction of the indices of the final scale, also the normality test was included in the multiple linear regression models where a value of the statistic was obtained lower than the significance of .005 , which demonstrated that the data were not distributed normally. On the other hand calculated the reliability of the instrument of use of sexual material online, reported that the global scale presents an acceptable Cronbach's alpha coefficient in this study $\alpha=.82$. which translates into a good fit.

Table 2 shows the frequencies and percentages of the use and type of online sexual material and the days of quar-
Table 1

Demographics $(n=385)$

\begin{tabular}{lrr}
\hline & $f$ & $\%$ \\
\hline Sex & 122 & 31.7 \\
Male & 263 & 68.3 \\
Female & & \\
Day of quarantine & 29 & 7.5 \\
Less than 10 days & 35 & 9.1 \\
Between 10 and 12 days & 39 & 10.1 \\
Between 12 and 14 days & 57 & 14.8 \\
Between 15 and 17 days & 81 & 21.1 \\
Between 18 and 20 days & 87 & 22.6 \\
More than 20 days & 57 & 14.8 \\
I don't remember & & \\
Marital status & 160 & 41.6 \\
Single & 89 & 23.1 \\
Married & 89 & 23.1 \\
In a dating relationship & 19 & 4.9 \\
In a committed relationship for marriage & 8 & 2.1 \\
Divorced & 20 & 5.2 \\
Other &
\end{tabular}

antine in two periods. The first was from 1 to 14 days, finding that the type of online sexual material of the Mexicans studied was mainly from internet pages with $47.5 \%$ use, followed by mobile chat applications with $41.5 \%$ and social networks with $23.2 \%$. In a smaller percentage were the types of online sexual material in video calls, video portals, online sex forums, and email.

In the period of the second group of 15 days or more there was a considerable increase in consumption of the type of sexual material online, where internet pages reached $83.8 \%$ of use, mobile chat applications had an increase of $121.8 \%$, social networks with $56.7 \%$ and with a lower use were video calls, video portals, online sex forums, and email. Table 3 shows the online sexual activities that Mexicans carried out in the period of 1 to 14 days of preventive social

Table 2

Type of online sexual material $(n=385)$

\begin{tabular}{lrrrrr}
\hline & \multicolumn{4}{c}{ Quarantine days } \\
\cline { 2 - 3 } \cline { 5 - 6 } Type of sexual material & \multicolumn{1}{c}{ From 1 to 14 days } & & 15 days or more \\
\cline { 2 - 3 } \cline { 5 - 6 } Internet pages & 182 & 47.5 & & 318 & 83.8 \\
Mobile chat applications & 160 & 45.1 & & 468 & 121.8 \\
Social networks & 86 & 23.2 & & 221 & 56.7 \\
Video calls & 66 & 17.9 & & 144 & 38.3 \\
Video portals & 38 & 10.6 & & 97 & 25.4 \\
Online sex forums & 37 & 8.9 & & 79 & 21.0 \\
E-mail & 25 & 4.6 & 36 & 10.1 \\
\hline
\end{tabular}

Note: Each participant could choose more than one answer which can be reflected in the frequencies and percentages of the type of material online. 
Table 3

Online sexual activities $(n=385)$

\begin{tabular}{lccccc}
\hline & \multicolumn{4}{c}{ Quarantine days } \\
\cline { 2 - 3 } \cline { 5 - 6 } Online sexual activity & $F$ & $\%$ & & $f$ & $\%$ \\
\cline { 2 - 3 } \cline { 2 - 3 } Mrom 1 to 14 days & & 15 days or more \\
\hline Excitation & 163 & 43.1 & & 335 & 87.2 \\
Stimulation & 132 & 34.7 & & 290 & 75.8 \\
Meeting people & 73 & 19.7 & & 180 & 47.2 \\
Adventure & 72 & 19.1 & & 181 & 48.8 \\
Images & 53 & 14.5 & & 142 & 37.6 \\
Cybersex & 51 & 13.3 & & 133 & 35.2 \\
\hline
\end{tabular}

isolation due to COVID-19, masturbation was the main one with $43.1 \%$, followed by excitement with $34.7 \%$, and stimulation with $19.7 \%$. The sexual activities with the lowest percentage of practice in the studied sample were meeting people, adventure, images, and cybersex. After 15 days or more of quarantine, Mexicans most frequently performed the sexual activities of masturbation with $87.2 \%$, excitation with $75.8 \%$, and stimulation with $47.2 \%$. It can be seen that all increased according to the days of social isolation; the least frequent sexual activities online were meeting people, adventure, images, and cybersex.

The multiple linear regression models through the method of successive steps it was obtained that the selection of the variables for each model was in a random way and according to its value of significant probability this method guarantees that the exploratory selection of introducing and extracting variables of the regression models follows a purely mathematical logic for what it was considered the most suitable technique for the present study.

Table 4 shows the results of the multiple linear regression models. With it, was possible to determine the relationships between the variables and their probability of prediction, in addition to showing the standardized coefficients. In the first instance, the multiple linear regression model showed the existence of a predictive relationship between the variables that is explained by the equation $\mathrm{Y}=$ masturbation, $\mathrm{X}_{1}$, excitation $(\beta=.35, p<.001), \mathrm{X}_{2}$ adventure $(\beta=.25, p<.001)$ and $\mathrm{X}_{3}$ cybersex $(\beta=.21, p<.001)$. The coefficient of determination was .55 and the mean square error was 8.99 .

The second model of multiple linear regression is explained with the following equation $\mathrm{Y}=$ excitation, $\mathrm{X}_{1}$, masturbation $(\beta=.34, p<.001), \mathrm{X}_{2}$ stimulation $(\beta=.30$, $p<.001)$ and $\mathrm{X}_{3}$ cybersex $(\beta=.15, p<.005)$. The coefficient of determination was calculated as .54 and the root mean square error was 3.94. In the third model there was also an explained relationship with the equation $\mathrm{Y}=$ stimulation, $\mathrm{X}_{1}$, excitation $(\beta=.36, p<.001), \mathrm{X}_{2}$ cybersex $(\beta=.35, p<.001)$, and $X_{3}$ adventure $(\beta=.15, p<.005)$. The coefficient of determination was .50 and a mean square error of 2.50. For the fourth model a predictive equation was obtained where $\mathrm{Y}=$ meeting people, $\mathrm{X}_{1}$, adventure $(\beta=.33$, $p<.001), \mathrm{X}_{2}$ pictures $(\beta=.21, p<.001)$ and $\mathrm{X}_{3}$ masturbation $(\beta=.18, p<.005)$. The coefficient of determination was calculated as .33 and a mean square error of 9.05.

In the fifth model the equation was $\mathrm{Y}=$ adventure, $\mathrm{X}_{1}$, masturbation $(\beta=.24, p<.001), \mathrm{X}_{2}$ meeting people $(\beta=.21$, $p<.001), \mathrm{X}_{3}$ pictures $(\beta=.20, p<.001)$ and $\mathrm{X}_{4}$ cybersex $(\beta=.17, p<.005)$. The coefficient of determination in .55 and mean square error in 9.09. The sixth model also demonstrated predictive relationships expressed in the following equation $\mathrm{Y}=$ cybersex, $\mathrm{X}_{1}$ pictures $(\beta=.29, p<.001), \mathrm{X}_{2}$ stimulation $(\beta=.24, p<.001), \mathrm{X}_{3}$ masturbation $(\beta=.14, p<$ $.005)$, and $X_{4}$ adventure $(\beta=.12, p<.005)$. The coefficient of determination resulted in .61 and a root mean square error of 9.09. And the last model was represented with the following equation $\mathrm{Y}=$ pictures, $\mathrm{X}_{1}$ cybersex $(\beta=.38, p<.001), \mathrm{X}_{2}$ adventure $(\beta=.24, p<.001), X_{3}$ meet people $(\beta=.10, p<.005)$.

Table 4

Predictive relationships from online sexual activities

\begin{tabular}{|c|c|c|c|c|c|c|}
\hline $\begin{array}{l}\text { Online sexu- } \\
\text { al activity }\end{array}$ & $R^{2}$ & MSE & Predictors & $\beta$ & $S E \beta$ & $\begin{array}{c}\beta \\
\text { standardized }\end{array}$ \\
\hline \multirow{4}{*}{$\begin{array}{l}\text { Masturba- } \\
\text { tion }\end{array}$} & \multirow[t]{4}{*}{.55} & \multirow[t]{4}{*}{8.99} & constant & 6.43 & .73 & \\
\hline & & & excitation & .38 & .04 & $.35^{\star *}$ \\
\hline & & & adventure & .35 & .06 & $.25^{* *}$ \\
\hline & & & cybersex & .39 & .09 & $.21^{* *}$ \\
\hline \multirow[t]{4}{*}{ Excitation } & \multirow[t]{4}{*}{.54} & \multirow[t]{4}{*}{3.94} & constant & 3.53 & .73 & \\
\hline & & & masturbation & .31 & .04 & $.34^{* *}$ \\
\hline & & & stimulation & .42 & .06 & $.30^{* *}$ \\
\hline & & & cybersex & .27 & .08 & $.15^{*}$ \\
\hline \multirow[t]{4}{*}{ Stimulation } & \multirow[t]{4}{*}{.50} & \multirow[t]{4}{*}{2.50} & constant & 2.91 & .51 & \\
\hline & & & excitation & .26 & .03 & $.36^{* *}$ \\
\hline & & & cybersex & .45 & .06 & $.35^{\star *}$ \\
\hline & & & adventure & .14 & .04 & $.15^{*}$ \\
\hline \multirow{4}{*}{$\begin{array}{l}\text { Meeting } \\
\text { people }\end{array}$} & \multirow[t]{4}{*}{.33} & \multirow[t]{4}{*}{9.05} & constant & -2.85 & .53 & \\
\hline & & & adventure & .33 & .06 & $.33^{* *}$ \\
\hline & & & pictures & .30 & .07 & $.31^{* *}$ \\
\hline & & & masturbation & .13 & .04 & $.18^{*}$ \\
\hline \multirow[t]{5}{*}{ Adventure } & \multirow[t]{5}{*}{.55} & \multirow[t]{5}{*}{9.09} & constant & .86 & .59 & \\
\hline & & & masturbation & .17 & .03 & $.24^{* *}$ \\
\hline & & & meet people & .21 & .04 & $.21^{* *}$ \\
\hline & & & pictures & .29 & .06 & $.20^{* *}$ \\
\hline & & & cybersex & .23 & .07 & $.17^{*}$ \\
\hline \multirow[t]{5}{*}{ Cybersex } & \multirow[t]{5}{*}{.61} & \multirow[t]{5}{*}{9.09} & constant & -5.54 & .31 & \\
\hline & & & pictures & .31 & .04 & $.29^{* *}$ \\
\hline & & & stimulation & .19 & .03 & $.24^{* *}$ \\
\hline & & & masturbation & .08 & .02 & $.14^{*}$ \\
\hline & & & adventure & .11 & .02 & $.12^{*}$ \\
\hline \multirow[t]{4}{*}{ Pictures } & \multirow[t]{4}{*}{.51} & \multirow[t]{4}{*}{1.20} & constant & 2.94 & .36 & \\
\hline & & & cybersex & .35 & .04 & $.38^{* *}$ \\
\hline & & & adventure & .17 & .03 & $.24^{* *}$ \\
\hline & & & meet people & .10 & .03 & $.10^{* *}$ \\
\hline
\end{tabular}

Note: $\mathrm{R} 2$ = determination coefficient, MSE = mean square error. ${ }^{*} p<.005 ;{ }^{* *} p<.001$. 


\section{DISCUSSION AND CONCLUSION}

Before starting to discuss the findings obtained it is necessary to point out some limitations of the present study. The results should be considered an approximation to the reality of internet users during preventive isolation. However, the condition of preventive isolation requires perhaps a longitudinal scope to quantify the use of sexual material online and make the pertinent comparisons. The other limitation is that while sexual risk exists from the consumption of sexual material online, online sexual activities are an approximation of sexual risk but do not measure behavior as such by persons. Therefore, it is necessary for future research to conduct a scrutiny of sexual behavior facilitated by the use of sexual material and sexual activities online.

Finally, it can be said that for future research, systematic random sampling is necessary to reduce selection bias. In this study, applying an online survey may not guarantee control of participants. However, it is important to point out that on issues of sexuality when handling sensitive information, online surveys are particularly recommended so that the participant answers without any risk of being identified after the study (Grove et al., 2013).

In this study most of the participants were women; the marital status of the participants was mostly single and the average age was 27 . As for the days of preventive social isolation that the participants had was more than 20 days that represented the majority with $22.6 \%$ of the sample. It is important to highlight that participants were alone when interacting with online sexual material and sexual activities online $41 \%$ of the sample did it this way. This can be explained because users found a greater privacy in their activities, besides that, due to the general recommendations of preventive social isolation by COVID-19, people had more time to spend on online activities. Non-essential activities was the indicator for the suspension of presence activities and this includes school activities, which may also explain that most of the participants of this study were young people (WHO, 2019).

For the sake of clarity we want to mention here again that most had more than 20 days of social confinement, especially people who have a high consumption of internet and use of sexual material and sexual activities online, young people were the main participants of this study, a similar result was found the age group of 15 to 49 years in studies of organizations that found the habits of internet combined with the use of sexual material and sexual activities online (AMIPCI, 2016; OEI, 2016). Privacy plays an important role in the use of online sexual material and activities; in intimacy it is possible to find greater consumption. Something that was also reported by Valdez Montero (2011).

With respect to the objective of the present study which was to quantify the impact on the use and type of online sexual material and to determine the predictors of online sexual activities in people in preventive social isolation due to COVID-19, the type of sexual material at 14 days it was mainly of internet pages, mobile chat applications and social networks, this has a simple explanation, since internet pages as well as social networks enjoy a particularity in the dissemination of online sexual material and is that these platforms provide simple access to information, in some cases in an anonymous way which generates a sense of privacy in users, in addition they are very popular especially in the young population. Otherwise what is observed in the less frequent type of sexual material such as video calls, video portals, online sex forums, and email, since the diffusion of online sexual material in these last platforms the identity of the users is mostly exposed which would explain its less frequent use, this was consistent with what was reported by Uzieblo \& Prescott (2020) they found a growth in the use of websites to access online sexual material during the social isolation due to COVID-19.

A similar situation was found in users with 15 days or more of preventive social isolation, resulting in a higher consumption of the same types of online sexual material; internet pages, mobile chat applications, and social networks, the least frequent were video calls, video portals, online sex forums, and email. This result can be explained by the fact that in internet pages and social networks such as WhatsApp it is relatively easy to find sexually explicit audiovisual material that is shared among users, and so the potential reach of online sexual material and people is very high because with just a few clicks this information reaches anyone connected to one of these platforms (Koletić et al., 2019).

This happens even more so with preventive social isolation when people spend more hours navigating through social networks (AMIPCI, 2016). As is the case in the social network Facebook, it is common to find videos of explicit sex even in combination with alcohol consumption likewise you can find groups in this social network where users are invited to receive pornographic material through messages in private or through a link these practices pose a risk because the viewer can assume what he sees in videos or images as a modeling of sexual behavior to be assumed in their personal lives and therefore could adopt risky sexual behavior as has been shown in other studies (Bontempi, Mugno, Bulmer, Danvers, \& Vancour, 2009; Shallo \& Mengesha, 2019).

Finally, the predictors of online sexual activities with the greatest statistical weight represented by typed beta values equal to or greater than $(\beta=.33)$, and in order of their predictive ability were the variables (cybersex, excitation, masturbation, and adventure) all with a statistical significance of $p<.001$. This can be explained by the fact that some of these variables are related to the main sexual activities and to the type of sexual material that participants performed online during the health contingency period for COVID-19, these predictors can be understood as high 
sexual risk factors where users of perform in real life, this was consistent with what was mentioned in other studies (Fernández Velasco, 2018; Ibarra et al., 2020; Subía-Arellano et al., 2020). These studies agreed that the use of online sexual material and online sexual activities are a projection and encourage the replication of observed behaviors as a means of learning. Furthermore, for future research it is important to take up these predictive variables to explain sexual risk behavior in cybernauts.

The findings of this study have an impact on the dynamics of our affected society and in an atypical context, so it will be necessary to further investigate the effects of the pandemic on sexual behavior, including psychological variables such as stress, the post-traumatic effect of the pandemic, and the impact produced as such on the sexual behavior of individuals, An important aspect in the prevention of sexual risk behavior due to preventive social isolation is to ultimately reduce the number of hours spent surfing the internet. The performance of activities not related to technology or internet use will be a protective factor in reducing the effects of the pandemic on sexual behavior.

The COVID-19 pandemic has modified the dynamics of the lives of millions of people world wide, as a result of this change the use of the internet is part of everyday life, the use of online sexual material is particularly common among young people, internet pages and social networks such as Facebook, WhatsApp, and Periscope, among other platforms is feasible to access explicit sex content and this could be a risk in modeling the sexual behavior of its viewers, online sexual practices such as masturbation, excitation, and stimulation are frequent in Mexicans isolated by the pandemic. The variables that predicted these practices were cybersex, excitation, masturbation, and adventure. It is important to be alert to the effects that the pandemic causes in relation to sexual risk behaviors, the magnitude of the pandemic on the sexual behavior of Mexicans is still unknown, however the results presented are generalizable in the population with characteristics similar to those of the present study and it is required to continue investigating the effects of the pandemic on the sexual health of Mexicans.

\section{Funding}

None.

\section{Conflict of interest}

The authors declare that they have no conflicts of interest.

\section{REFERENCES}

Asociación Mexicana de Internet [AMIPCI]. (2016). 12 $2^{a}$ Estudio sobre los Hábitos de los Usuarios de Internet en México 2016 (pp. 1-5). Retrieved from https://www. asociaciondeinternet.mx/estudios/habitos-de-internet

Bandura, A. (2011). The social and policy impact of social cognitive theory. In M. Mark, S. Donaldson, \& B. Campbell (Eds.). Social psychology and evaluation (pp. 33-70). New York, NY: Guilford Press.
Benavides, R. A., Valdez Moreno, C., González, V. M., \& Onofre Rodríguez, D. J. (2012). Use of Sexual Material Online and At-Risk Sexual Behavior Regarding HIV/AIDS among College Students. In NI 2012: 11th International Congress on Nursing Informatics, June 23-27, 2012, Montreal, Canada. (Vol. 2012). American Medical Informatics Association.

Bontempi, J. B., Mugno, R., Bulmer, S. M., Danvers, K., \& Vancour, M. L. (2009). Exploring gender differences in the relationship between HIV/STD testing and condom use among undergraduate college students. American Journal of Health Education, 40(2), 97-105. doi: 10.1080/19325037.2009.10599084

Castillo-Arcos, L., Benavides-Torres, R. A., \& López-Rosales, F. (2012). Intervención por Internet para Reducir Conductas Sexuales de Riesgo para VIH/SIDA: Una Propuesta Innovadora. Desarrollo Científico de Enfermería, 20(8), 266-270. Retrieved from http://www.index-f.com/dce/20pdf/20-266.pdf

Cohen, J. (2013). Statistical Power Analysis for the Behavioral Sciences. New York, NY: Academic Press.

Eversole, J. S., Berglas, N. F., Deardorff, J., \& Constantine, N. A. (2017). Source of Sex Information and Condom Use Intention Among Latino Adolescents. Health Education \& Behavior, 44(3), 439-447. doi: 10.1177/1090198116671704

Fernández Velasco,V. (2018). Influencia de internet en la educación sexual de los adolescentes y el papel de enfermería. Universidad Complutense Madrid. Retrieved from https://eprints.ucm.es/51624/

Fishbein, M., \& Ajzen, I. (2011). Predicting and changing behavior: The reasoned action approach. New York, NY: Taylor \& Francis.

Folch, C., Álvarez, J. L., Casabona, J., Brotons, M., \& Castellsagué, X. (2015). Determinantes de las conductas sexuales de riesgo en jovenes de Cataluña. Revista Española de Salud Pública, 89(5), 471-485. doi: 10.4321/s113557272015000500005

García-Vega, E., Menéndez, E., Fernández, P., \& Cuesta, M. (2012). Sexualidad, Anticoncepción y Conducta Sexual de Riesgo en Adolescentes. International Journal of Psychological Research, 5(1) 79-87.

Glanz, K., Rimer, B. K., \& Viswanath, K. (Eds.). (2008). Health behavior and health education: theory, research, and practice. San Francisco, CA: John Wiley \& Sons, Inc.

Grove, S. K., Burns, N., \& Gray, J. (2013). The Practice of Nursing Research: Appraisal, Synthesis, And Generation of Evidence. St. Louis, Missouri: Elsevier Health Sciences.

Hald, G. M., Kuyper, L., Adam, P. C. G., \& de Wit, J. B. F. (2013). Does Viewing Explain Doing? Assessing the Association Between Sexually Explicit Materials Use and Sexual Behaviors in a Large Sample of Dutch Adolescents and Young Adults. The Journal of Sexual Medicine, 10(12), 2986-2995. doi: 10.1111/ jms. 12157

Hernández Torres, J. L., Benavides Torres, R. A., González y González, V., \& Onofre Rodríguez, D. J. (2019). Prototipo móvil para fomentar el uso de condón en jóvenes mexicanos: un estudio de caso. Revista Cubana de Informática Médica, 11(2), 65-79.

Hernández Torres, J. L., Benavides Torres, R. A., Onofre Rodríguez, D. J., \& Jiménez Vázquez, V. (2018). Valoración cualitativa de cuidado en jóvenes mexicanos con riesgo de VIH/Sida. Revista Científica de Enfermería, 15, 5-18. doi: 10.14198/recien.2018.15.02

Ibarra, F. P., Mehrad, M., Di Mauro, M., Godoy, M. F. P., Cruz, E. G., Nilforoushzadeh, M. A., \& Russo, G. I. (2020). Impact of the COVID-19 pandemic on the sexual behavior of the population. The vision of the east and the west. International Braz J Urol, 46(Suppl. 1), 104-112. doi: 10.1590/s1677-5538.ibju.2020.s116

Koletić, G., Štulhofer, A., Tomić, I., \& Knežević Ćuća, J. (2019). Associations between Croatian adolescents' use of sexually explicit material and risky sexual behavior: A latent growth curve modeling approach. International Journal of Sexual Health, 31(1) 77-91. doi: 10.1080/19317611.2019.1567640

Miles, M. B., Huberman, A. M., \& Saldana. J. (2013). Qualitative data analysis. A Methods Sourcebook. Sage publications.

Organización de Estados Iberoamericanos [OEI]. (2016). Cibersexo: Encuesta 2016 para conocer la conducta sexual del mexicano en internet. Retrieved from https://www.oei.es/historico/divulgacioncientifica/?Cibersexo-Encuesta-2016para-conocer-la-conducta-sexual-del-mexicano-en

Prochaska, J. O., Velicer, W. F., Rossi, J. S., Goldstein, M. G., Marcus, B. H., Rakowski, W., ... Rossi, S. R. (1994). Stages of change and decisional balance 
for 12 problem behaviors. Health Psychology, 13(1) 39-46. doi: 10.1037/02786133.13.1.39

Secretaría de Salud [SSA]. (1987). Reglamento de Ley General de Salud en Materia de Investigación para la Salud. Diario Oficial. Retrieved from http://www.salud. gob.mx/unidades/cdi/nom/compi/rlgsmis.html

Shallo, S. A., \& Mengesha, W. W. (2019). Exposure to Sexually Explicit Materials and Its Association with Sexual Behaviors of Ambo University Undergraduate Students, 2018. Ethiopian Journal of Health Sciences, 29(4), 461-470. doi: 10.4314/ejhs.v29i4.7

Subía-Arellano, A., Muñoz, N., \& Navarrete, A. (2020). Comportamiento sexual y aislamiento social a causa del COVID-19. CienciAmérica, 9(2), 256-260. doi: 10.33210/ca.v9i2.315

Uzieblo, K., \& Prescott, D. (2020). Online pornography use during the COVID-19 pandemic: Should we worry? Part I. Sexual Abuse-blogspot, 1-3.

Valdez Montero, C. (2011). Uso De Material Sexual En Linea Y Conducta Sexual De Riesgo para VIH/SIDA en jovenes universitarios. (Doctoral dissertation). Universidad Autónoma de Nuevo León. Retrieved from http://eprints.uanl. mx/2901/1/1080211210.pdf
Valdez Montero, C. M., Benavides Torres, R. A., González y González, V., Onofre Rodríguez, D. J., \& Castillo Arcos, L. (2015). Internet and sexual risk behavior for HIV/AIDS in young people. Enfermeria Global, 14(38), 151-159. Retrieved from http://scielo.isciii.es/scielo.php?script=sci arttext\&pid=S1695$61412015000200008 \&$ lang $=\mathrm{pt}$

World Health Organization [WHO]. (2019). Situación de COVID-19 en la Región de las Américas. Rerieved from https://www.paho.org/es/temas/coronavirus/broteenfermedad-por-coronavirus-COVID-19

Yzer, M. C. (2012). The integrative model of behavioral prediction as a tool for designing health messages: Yheory and practise. In Cho, H. (Ed.). (2011). Designing Messages for Health communication: Theory and Practice. Sage Publications, Thousand Oaks, CA. Retrieved from https://experts.umn.edu/en/ publications/the-integrated-model-of-behavioral-prediction-as-a-tool-for-desig 